\title{
Transport, ultrastructural localization, and distribution of chemical forms of lead in radish (Raphanus sativus L.)
}

\author{
Yan Wang ${ }^{1+}$, Hong Shen ${ }^{1+}$, Liang $\mathrm{Xu}^{1+}$, Xianwen $\mathrm{Zhu}^{2}$, Chao $\mathrm{Li}^{1}$, Wei Zhang ${ }^{1}$, \\ Yang Xie ${ }^{1}$, Yiqin Gong ${ }^{1}$ and Liwang Liu ${ }^{1 *}$ \\ ${ }^{1}$ National Key Laboratory of Crop Genetics and Germplasm Enhancement, College of Horticulture, Nanjing Agricultural \\ University, Nanjing, China, ${ }^{2}$ Department of Plant Sciences, North Dakota State University, Fargo, ND, USA
}

\section{OPEN ACCESS}

Edited by:

David W. M. Leung,

University of Canterbury, New Zealand

Reviewed by:

Gijs A. Kleter,

Wageningen University and Research

Centre, Netherlands

Juan Miguel Gomez Bernal,

Universidad Nacional Autónoma de

México, Mexico

${ }^{*}$ Correspondence:

Liwang Liu,

National Key Laboratory of Crop

Genetics and Germplasm

Enhancement, College of Horticulture,

Nanijing Agricultural University,

Weigang No.1, Nanjing 210095, China

nauliulw@njau.edu.cn

${ }^{t}$ These authors have contributed equally to this work.

Specialty section: This article was submitted to Plant Biotechnology,

a section of the journal

Frontiers in Plant Science

Received: 20 November 2014

Accepted: 11 April 2015

Published: 08 May 2015

Citation:

Wang Y, Shen H, Xu L, Zhu X, Li C, Zhang $W$, Xie $Y$, Gong $Y$ and Liu $L$ (2015) Transport, ultrastructural localization, and distribution of chemical forms of lead in radish

(Raphanus sativus L.)

Front. Plant Sci. 6:293.

doi: $10.3389 /$ fpls.2015.00293
Lead $(\mathrm{Pb})$, a ubiquitous but highly toxic heavy metal $(\mathrm{HM})$, is harmful to human health through various pathways including by ingestion of contaminated vegetables. Radish is a worldwide root vegetable crop with significant health and nutritional benefits. However, little is known about $\mathrm{Pb}$ translocation and distribution within radish plants after its uptake by the roots. In this study, $\mathrm{Pb}$ stress was induced using $\mathrm{Pb}\left(\mathrm{NO}_{3}\right)_{2}$ in hydroponic culture, aiming to characterize the transport, ultrastructural localization, and distribution of chemical forms of $\mathrm{Pb}$ in different tissues of radish. The results showed that the majority of $\mathrm{Pb}$ (85.76-98.72\%) was retained in underground organs including lateral roots, root heads and taproot skins, while a small proportion of $\mathrm{Pb}$ was absorbed by root flesh (0.44-1.56\%) or transported to the shoot (1.28-14.24\%). A large proportion of $\mathrm{Pb}$ (74.11-99.30\%) was integrated with undissolved $\mathrm{Pb}$ oxalate, protein and pectates forming $\mathrm{Pb}$-phosphate complexes. Moreover, a low-Pb-accumulating line of radish showed a higher proportion of $\mathrm{Pb}$ in water-soluble form compared with a high-Pb-accumulating line. Subcellular distribution analysis showed that a large proportion of $\mathrm{Pb}$ was bound to cell wall fraction in lateral roots $(71.08-80.40 \%)$ and taproot skin (46.22-77.94\%), while the leaves and roots had 28.36-39.37\% and $27.35-46.51 \%$ of $\mathrm{Pb}$ stored in the soluble fraction, respectively. Furthermore, transmission electron microscopy (TEM) revealed $\mathrm{Pb}$ precipitates in intercellular space, cell wall, plasma lemma and vacuoles. Fractionation results also showed the accumulation of $\mathrm{Pb}$ on the cell wall, intercellular space and vacuole, and low uptake of undissolved $\mathrm{Pb}$ oxalate, protein, pectates and $\mathrm{Pb}$-phosphate complexes, which might be due to low transport efficiency and $\mathrm{Pb}$ tolerance of radish. These findings would provide insight into molecular mechanism of $\mathrm{Pb}$ uptake and translocation in radish and facilitate development of low-Pb-content cultivars in root vegetable crops.

Keywords: radish (Raphanus sativus L.), lead, chemical form, subcellular distribution, translocation

\section{Introduction}

Contamination by heavy metals (HMs) has become a worldwide environmental problem, because the metals easily accumulate in soil and are difficult to volatilize, dissolve or be decomposed by soil 
microorganisms (Cui and Zhang, 2004; Abou-Shanab et al., 2007; Zhang et al., 2012). Lead (Pb) is one of the five most toxic HMs and is harmful to human beings and other creatures (Wang et al., 2013). Other than natural weathering processes, the main source of contamination of agricultural soils and water by $\mathrm{Pb}$ is usually a direct or indirect consequence of anthropogenic activities (McLaughlin and Singh, 1999; Sharma and Dubey, 2005). The sources of anthropogenic contamination include $\mathrm{Pb}$-using industries such as battery manufacture, metal mining and smelting (Capdevila et al., 2003; Caussy et al., 2003), urban and industrial wastes (Singh, 2001), fumes of automobiles and industry, fertilizers, pesticides, and additives (Eick et al., 1999). In some industrial cities, urban soils are heavily polluted with $\mathrm{Pb}$ and the mean $\mathrm{Pb}$ concentration is much higher than its background value (Lu et al., 2003; Li et al., 2013).

$\mathrm{Pb}$ is easily absorbed by plants and accumulates in different tissues (Sharma and Dubey, 2005), then endangering human health through the food chain. $\mathrm{Pb}$ is toxic to many organ systems of the human body, such as the renal system, the cardiovascular system, the reproductive system, and the nervous system, leading to anemia, changes to sperm morphology and function, neurological disorders, renal tubular damage, a weakened immune system, hyperactivity, and enzyme changes (Gidlow, 2004; Liu et al., 2013). Therefore, $\mathrm{Pb}$ uptake, transport and accumulation in plants, particularly in edible parts, have attracted much attention (Liu et al., 2013). Although $\mathrm{Pb}$ is not an essential element for plants, many studies have indicated that some plants can absorb $\mathrm{Pb}$ through roots and translocate it to shoots (Tangahu et al., 2011; Liu et al., 2013; Wójcik and Tukiendorf, 2014). A large amount of lead was accumulated in roots, but only lower levels of $\mathrm{Pb}$ were translocated into shoots of water hyacinth seedlings (Malar et al., 2014). However, different plant species and plant organs may differ significantly in their ability to absorb, transport, and accumulate $\mathrm{Pb}$ (Alexander et al., 2006; Weng et al., 2009; Liu et al., 2010; Zhang et al., 2012). Furthermore, the accumulation and transport efficiency may vary within the same plant species depending on their genetic backgrounds (Su et al., 2014).

HM accumulation in plants is determined by many factors such as medium conditions (soil, nutrients, air), the uptake capacity of roots, the efficiency of translocation, and the distribution and redistribution of the metal among plant tissues (Zheng et al., 2011). It has been reported that differences in $\mathrm{Pb}$ translocation within plants may result from different chemical forms of $\mathrm{Pb}$ (Liu et al., 2013). The transport, toxicity and biological validity of HMs in plants are closely related to their subcellular distribution and chemical form of HMs in plants (Wang et al., 2008). Chemical speciation and distribution characteristics of HMs in plants also affect the uptake and tolerance of plants to HMs (Wang et al., 2008). In roots, $\mathrm{Pb}$ immobilization is mainly due to the complexing ability of histidine, and the transport to the upper plant organs is mainly attributed to $\mathrm{Pb}$ complexes with organic acids (Massaccesi et al., 2014). Patterns of subcellular distribution and chemical forms of HM in plant are important reflections of plant accumulation and detoxification processes (Wang et al., 2008; Xu et al., 2011). Chemical forms and subcellular distribution differ greatly among HMs, plant species, cultivars, and ecotypes ( $\mathrm{Wu}$ et al., 2005; Wang et al., 2008; Xu et al., 2011). Pb taken up by roots can be deposited at many sites in the tissue (Inoue et al., 2013). Recent studies of root cells of Pisum sativa under high $\mathrm{Pb}$ stress have shown that $\mathrm{Pb}$ mainly accumulated on the cell wall, the cell membrane, cell voids, mitochondria, and peroxisomes (Malecka et al., 2008). A study of Sedum alfredii also found that $\mathrm{Pb}$ accumulated mainly on the cell wall and very little was found on the membrane fraction of roots, stem, and leaves (He et al., 2003).

Radish (Raphanus sativus L.), belonging to the Brassicaceae family, is an important vegetable crop worldwide, especially in East Asia. Recently, large phenotypic variations in root uptake and concentration of $\mathrm{Pb}$ among different tissues in radish plants were observed. Radish roots and hypocotyls accumulated 50\% and $35 \%$ of the total lead content, respectively (Massaccesi et al., 2014). Pb particles were mainly deposited in the intercellular space, and only a small proportion was found in the cell wall of radish roots (El-Beltagi and Mohamed, 2010). However, another study indicated that $\mathrm{Pb}$ was deposited in the cell wall and vacuoles in lateral roots but not in the taproot (Inoue et al., 2013). To characterize the genotypic differences of $\mathrm{Pb}$ absorption as well as the accumulation, in our previous study, a hydroponic culture supplemented with $\mathrm{Pb}\left(\mathrm{NO}_{3}\right)_{2}$ was carried out for 36 radish genotypes which were selected based on their main traits including skin and flesh color, taproot shape, and size. The results showed that root $\mathrm{Pb}$ concentrations varied significantly among various radish genotypes and the concentration of the highest $\mathrm{Pb}$ accumulation genotype was about 7.5 times higher than that of the lowest one. Some high-accumulation genotypes including "NAU-XLM," "NAU-CH," and low-accumulation ones including "NAU-XHT" and "NAU-YH" were identified (Shen et al., 2015). Although $\mathrm{Pb}$ uptake by plant roots has been studied extensively, little is known about the translocation and distribution of $\mathrm{Pb}$ within radish plants. The aims of this study were to investigate: (1) the transport of $\mathrm{Pb}$ within intact radish plants under different $\mathrm{Pb}$ regimes; (2) subcellular distribution and chemical forms of $\mathrm{Pb}$ among various parts of radishes under different $\mathrm{Pb}$ regimes; and (3) $\mathrm{Pb}$ localization in radish root cells. The results revealed the characteristics of $\mathrm{Pb}$ uptake, transport, and distribution in radish, which may provide valuable information for better understanding of the molecular mechanism of $\mathrm{Pb}$ translocation in radish and for further development of low- $\mathrm{Pb}$-content vegetable crops.

\section{Materials and Methods}

\section{Plant Materials}

Two advanced inbred lines of radish, "NAU-XLM" (high-Pbaccumulation) and "NAU-XHT" (low-Pb-accumulation), which were self-pollinated for more than 20 generations, were used for the study of $\mathrm{Pb}$ accumulation and transport as well as analysis of subcellular distribution and chemical forms of $\mathrm{Pb}$. Additionally, the "NAU-XLM" was chosen to investigate Pb localization in root cells.

\section{Hydroponic Experiment and Plant Sampling}

Seeds of radish were firstly surface sterilized and then incubated at $25^{\circ} \mathrm{C}$ in the dark. The germinated seeds were sown in 
plastic pots containing soil and nursery substrate (soil: turf: vermiculite $=1: 1: 1$ ) in a greenhouse. After 1 month, radish seedlings of similar size were selected and transferred to the modified half-strength Hoagland's nutrient solution (Wang et al., 2013). The solution was renewed every 4 days. A week later, seedlings of the two genotypes were treated with 0,200 and $500 \mathrm{mg} / \mathrm{L}$ $\mathrm{Pb}\left(\mathrm{NO}_{3}\right)_{2}$ for 2, 4, 6, 8 days. Each treatment consisted of three replicates. For the amount of plant parts from one individual is not enough for digestion and $\mathrm{Pb}$ concentration measurement, the plant parts from three randomly selected plants of each replicate with five individuals were pooled to get sufficient amount of samples.

The plants were immersed in $0.02 \mathrm{~mol} / \mathrm{L} \mathrm{Na}_{2}$ EDTA for $20 \mathrm{~min}$, and then rinsed with deionized water. Thereafter, the plants of the NAU-XLM were separated into leaves, petioles, roots, and lateral roots (LR), whilst the plants of the NAU-XHT were separated into leaves, petioles, root heads (dwarf stem), root necks (the upper root that originates from the hypocotyl, without lateral roots), true roots (the lower root that consists of true root tissue), the skins of these parts and lateral roots. For each replicate, the same plant parts which had been obtained from the three selected individuals were pooled with the amount of about $2.0 \mathrm{~g}$ in fresh weight except the LR with amount of about $0.4 \mathrm{~g}$. Samples were dried in an oven overnight at $70^{\circ} \mathrm{C}$ to constant weight and then ground into fine powder. And then approximately $0.2 \mathrm{~g}$ samples $(\sim 0.1 \mathrm{~g}$ for $\mathrm{LR})$ were weighed with $5.0 \mathrm{~mL}$ mixture of concentrated $\mathrm{HNO}_{3}-\mathrm{HClO}_{4}(4: 1, \mathrm{v} / \mathrm{v})$, which were well-mixed and left to stand for at least $12 \mathrm{~h}$ at room temperature. The digestion was carried out in a heating block using the temperature program according the previous study by Zhao et al. (1994). The samples were evaporated to dryness with a final temperature of $180^{\circ} \mathrm{C}$. After digestion and cooling, $10 \mathrm{ml}$ of $\mathrm{HNO}_{3}$ $(2.5 \% \mathrm{v} / \mathrm{v})$ was added, which were mixed and rewarmed at $80^{\circ} \mathrm{C}$ for 30-60 min. For Atomic Absorption spectrophotometry (AAS) measurement, each treatment consisted of three replicates. Each replicate was measured three times.

\section{Tissue Fractionation and Chemical form Extraction}

For analysis of subcellular distribution and chemical forms of $\mathrm{Pb}$, the plants were immersed in $0.02 \mathrm{~mol} / \mathrm{L} \mathrm{Na}_{2}$ EDTA, rinsed with deionized water and separated into leaves, roots without skins, skins, and lateral roots. Fresh samples $(0.5 \mathrm{~g})$ were homogenized in pre-cooled extraction buffer containing $0.25 \mathrm{~mol} / \mathrm{L}$ sucrose, $0.05 \mathrm{~mol} / \mathrm{L}$ Tris- $\mathrm{HCl}$ ( $\mathrm{pH} 7.5$ ) and $0.001 \mathrm{~mol} / \mathrm{L}_{4} \mathrm{CH}_{10} \mathrm{O}_{2} \mathrm{SS}_{2}$. Cells were separated into four fractions (F1-F4) with differential centrifugation technique (Weigel and Jäger, 1980; Zhou et al., 2008). The homogenate was centrifuged at $300 \mathrm{~g}$ for $30 \mathrm{~s}$ and the precipitation was designated as cell wall fraction (F1) mainly consisting of cell walls and cell wall debris, the resulting supernatant solution was further centrifuged at $2000 \mathrm{~g}$ for 15 min mainly consisting of chloroplasts and cell nuclei (F2), the supernatant solution was further centrifuged at $10,000 \mathrm{~g}$ for $20 \mathrm{~min}$, referring to as mitochondrial components (F3), and soluble components containing ribosomes (F4, the supernatant), respectively. All steps were performed at $4^{\circ} \mathrm{C}$.

The chemical forms of $\mathrm{Pb}$ were extracted using a sequence of different extractants (Xu et al., 1991; Xu and Wang, 2013):
(1) $80 \%$ ethanol, extracting inorganic $\mathrm{Pb}$ including nitrate/nitrite, chloride; (2) Deionized water $\left(\mathrm{d}-\mathrm{H}_{2} \mathrm{O}\right)$, extracting water-soluble $\mathrm{Pb}$-organic acid complexes and $\mathrm{Pb}\left(\mathrm{H}_{2} \mathrm{PO}_{4}\right)_{2} ;$ (3) $1 \mathrm{~mol} / \mathrm{L} \mathrm{NaCl}$, extracting pectates, protein integrated or adsorptive $\mathrm{Pb}$; (4) $2 \%$ acetic acid (HAC), extracting undissolved lead phosphate including $\mathrm{PbHPO}_{4}$ and $\mathrm{Pb}_{3}\left(\mathrm{PO}_{4}\right)_{2}$ and other $\mathrm{Pb}$-phosphate complexes; (5) $0.6 \mathrm{~mol} / \mathrm{L} \mathrm{HCl}$, extracting lead oxalate; and (6) $\mathrm{Pb}$ in residues. Fresh tissue ( $2 \mathrm{~g}$ ) was cut into small pieces of $1-2 \mathrm{~mm}^{2}$ and transferred into a beaker with $25 \mathrm{ml}$ extraction solution. Mixture was incubated at $30^{\circ} \mathrm{C}$ (about $17-18 \mathrm{~h}$ ) and then the extraction solution was pooled. The residues were extracted again with the same extraction solution $(25 \mathrm{ml})$ for another $2 \mathrm{~h}$, which was repeated twice in the next $4 \mathrm{~h}$. A total of $100 \mathrm{ml}$ extraction solution was collected and evaporated to constant weight, and then digested with $\mathrm{HNO}_{3}-\mathrm{HClO}_{4}(4: 1, \mathrm{v} / \mathrm{v})$ for determination. After collection of the former extraction solution, the plant materials retained in the beaker were subjected to the next extractant with the similar procedures. For determination of $\mathrm{Pb}$ in residues, plant material was digested with $\mathrm{HNO}_{3}-\mathrm{HClO}_{4}(4: 1, \mathrm{v} / \mathrm{v})$ at the end of the sequential extraction. Lead concentrations associated with different chemical forms were determined by AAS (AAnalyst 700, Perkin-Elmer,USA) (Xu et al., 1991; Xu and Wang, 2013).

\section{Ultrastructural Localization of $\mathrm{Pb}$ using Transmission Electron Microscopy (TEM)}

One to two millimeter ( $\mathrm{mm}$ ) sections of treated roots and lateral roots of the NAU-XLM were fixed in $2.5 \%$ glutaraldehyde $(\mathrm{v} / \mathrm{v})$ in $0.2 \mathrm{~mol} / \mathrm{L}$ sodium phosphate buffer of $\mathrm{pH} 7.2$ at $4^{\circ} \mathrm{C}$ for $12 \mathrm{~h}$. The tissues were rinsed three times ( $1 \mathrm{~h}$ each time) in 0.2 $\mathrm{mol} / \mathrm{L}$ phosphate buffer ( $\mathrm{pH}$ 7.2). After that, the samples were post fixed in $1 \%(\mathrm{v} / \mathrm{w}) \mathrm{OsO}_{4}$ for $2 \mathrm{~h}$, then rinsed three times $(1 \mathrm{~h}$ per time) in $0.2 \mathrm{M}$ phosphate buffered solution ( $\mathrm{pH}$ 7.2). Samples were dehydrated using a graded acetone and ethanol series (30, $50,70,80$, and $90 \%)$, then the tissues were infiltrated and embedded in Spurr's resin and cut into ultrathin slices $(80 \mathrm{~nm})$ using a Power Tome-XL microtome. They were finally mounted on copper grids and observed using a transmission electron microscope (TEM, Hitachi $\mathrm{H}-7650$ ), at an accelerating voltage of $80 \mathrm{keV}$ (Lu et al., 2012).

\section{$\mathrm{Pb}$ Concentration Determination and Data Analysis}

$\mathrm{Pb}$ concentration was determined using AAS (AAnalyst 700, Perkin-Elmer, USA) (Liu et al., 2010). The data obtained was analyzed with the statistical package of IBM SPSS Statistics v20.0 and EXCEL2010, and the graphs were produced with the EXCEL 2010.

\section{Results}

\section{$\mathrm{Pb}$ Uptake of in the High-Pb-Accumulation Line NAU-XLM}

In hydroponic culture conditions, as compared with control, no special obvious morphologic differences were found among individuals exposed to $200 \mathrm{mg} / \mathrm{L} \mathrm{Pb}\left(\mathrm{NO}_{3}\right)_{2}$ for a maximum of 6 days, while the plants were hampered and grew abnormally when exposed to $500 \mathrm{mg} / \mathrm{L} \mathrm{Pb}\left(\mathrm{NO}_{3}\right)_{2}$ after 6 days. Some plants were wilting and some mature leaves were rolling in chlorosis, and 
the root enlargement, and shoot elongation were relatively inhibited. The $\mathrm{Pb}$ concentration in each part of the radish increased with increasing $\mathrm{Pb}$ treatment duration and concentrations, but was always greatest in lateral roots (Supplementary Table 1). The results indicated that the NAU-XLM can accumulate large amounts of $\mathrm{Pb}$ in their tissues, for example, under a treatment of $500 \mathrm{mg} / \mathrm{L} \mathrm{Pb}\left(\mathrm{NO}_{3}\right)_{2}$, the concentration of lead in roots increased from $1265.50 \mathrm{mg} / \mathrm{kg}$ on the second day to $2434.67 \mathrm{mg} / \mathrm{kg}$ on the eighth day. The $\mathrm{Pb}$ concentrations varied considerably among tissues. Under a treatment of $200 \mathrm{mg} / \mathrm{L} \mathrm{Pb}\left(\mathrm{NO}_{3}\right)_{2}$, the distribution of $\mathrm{Pb}$ concentration among tissues followed the order of lateral roots $>>$ leaves $>$ roots $>$ petioles; however, under $500 \mathrm{mg} / \mathrm{L}$ $\mathrm{Pb}\left(\mathrm{NO}_{3}\right)_{2}$, the order was lateral roots $>>$ roots $>$ leaves $>$ petioles. $\mathrm{Pb}$ concentrations in lateral roots increased $11.8 \%$ and $11.3 \%$ under $200 \mathrm{mg} / \mathrm{L}$ and $500 \mathrm{mg} / \mathrm{L}$ treatments, respectively, from the second day to the fourth day, and then showed a small increase by 39.1 and 35.3\%, respectively, in the next 4 days (Figure 1A). Root $\mathrm{Pb}$ concentrations showed a similar trend (Figure 1B). Pb concentrations in petioles had the largest increase, during the first 4 days, representing $9.0 \%$ and $8.5 \%$ under 200 and $500 \mathrm{mg} / \mathrm{L} \mathrm{Pb}$ treatments, respectively, after which the rate of increase declined with a final increase by $19.1 \%$, and $25 \%$ over the last 2 days (Figure 1C). A similar pattern appeared in $\mathrm{Pb}$ concentrations in the leaves under $\mathrm{Pb}$ treatments of 200 and $500 \mathrm{mg} / \mathrm{L}$, but the scale of increase was smaller (Figure 1C).

\section{$\mathrm{Pb}$ Uptake in the Low-Pb-Accumulation Line NAU-XHT}

When compared to their corresponding control, the results indicated that the NAU-XHT can also accumulate lots of $\mathrm{Pb}$ in their tissues (Supplementary Table 2). The $\mathrm{Pb}$ concentrations in tissues of the NAU-XHT varied considerably under treatment of $200 \mathrm{mg} / \mathrm{L} \mathrm{Pb}\left(\mathrm{NO}_{3}\right)_{2}$. In general, $\mathrm{Pb}$ concentration in the tissues followed the order: lateral roots $>>$ leaves $>$ root heads $>$ skin of true root $>$ skin of root neck $>$ petioles $>$ true root flesh $>$ root neck flesh. However, on the eighth day, the order of $\mathrm{Pb}$ concentration was lateral roots $>>$ skin of true root $>$ root heads $>$ leaves $>$ skin of root neck $>$ petioles $>$ true root flesh $>$ root neck flesh. Under the treatment of $500 \mathrm{mg} / \mathrm{L} \mathrm{Pb}\left(\mathrm{NO}_{3}\right)_{2}$, the order was lateral roots $>>$ skin of true root $>$ root heads $>$ skin of root neck $>$ leaves $>$ petioles $>$ true root flesh $>$ root neck flesh, except on the second day, when the order was lateral roots $>>$ root heads $>$ skin of true root $>$ skin of root neck $>$ leaves $>$ true root flesh $>$ petioles $>$ root neck flesh.

The rate of increase in $\mathrm{Pb}$ uptake in lateral roots increased gradually, showing $9.5 \%$ and $10.8 \%$ increase from day 2 to day 4 , and $61 \%$ and $230.7 \%$ increase from day 6 to day 8 under the $\mathrm{Pb}$ treatment of $200 \mathrm{mg} / \mathrm{L}$ and $500 \mathrm{mg} / \mathrm{L}$, respectively (Figure 2A). The rate of $\mathrm{Pb}$ uptake in skins of true root decreased gradually, initially increasing by $193 \%$ from day 2 to day 4 , and finally $15.7 \%$ from day 6 to day 8 under the $500 \mathrm{mg} / \mathrm{L} \mathrm{Pb}$
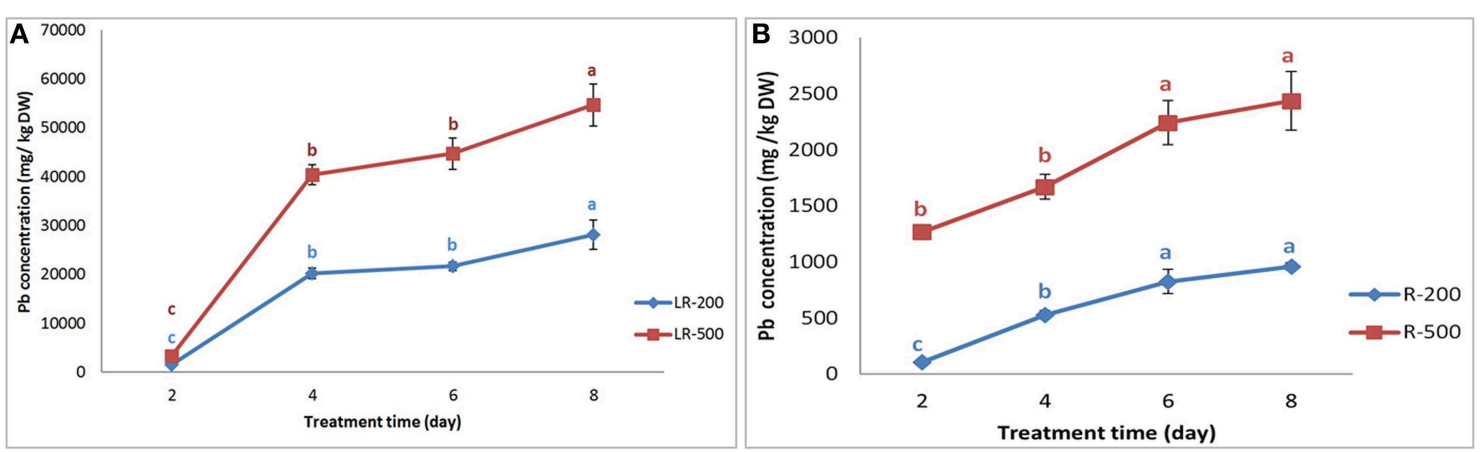

C

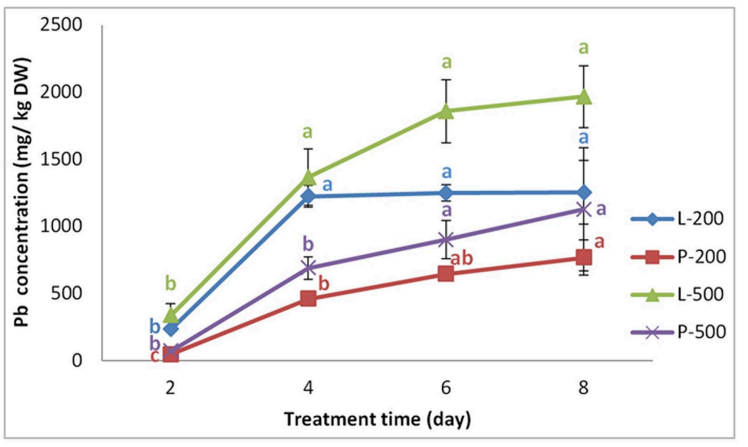

FIGURE 1 | Variation in the $\mathrm{Pb}$ concentration in different parts of NAU-XLM. Panels $(\mathbf{A}, \mathbf{B})$ represent the $\mathrm{Pb}$ concentration in lateral roots $(\mathrm{LR})$ and roots (R), respectively. LR-200 and $\mathrm{R}-200$ was lateral roots and roots treated with $200 \mathrm{mg} / \mathrm{L} \mathrm{Pb}\left(\mathrm{NO}_{3}\right)_{2}$; while $\mathrm{LR}-500$ and $\mathrm{R}-500$ was lateral roots and roots treated with $500 \mathrm{mg} / \mathrm{L} \mathrm{Pb}\left(\mathrm{NO}_{3}\right)_{2}$. Panel (C) represents the $\mathrm{Pb}$ concentration in leaves $(\mathrm{L})$ and petioles $(\mathrm{P})$. $\mathrm{L}-200$ and P-200 were leaves and petioles treated with $200 \mathrm{mg} / \mathrm{L} \mathrm{Pb}\left(\mathrm{NO}_{3}\right)_{2} ; \mathrm{R}-500$ and $\mathrm{P}-500$ were leaves and petioles treated with $500 \mathrm{mg} / \mathrm{L} \mathrm{Pb}\left(\mathrm{NO}_{3}\right)_{2}$. Data are the mean \pm SE $(n=3)$ and different letters (lowercase) indicate significant differences at $P<0.05$. 
treatment (Figure 2B). However, $\mathrm{Pb}$ concentrations in the skins of true roots increased by $40.8 \%$ from day 2 to day 4 , and then decreased by $4.3 \%$ from day 4 to day 6 , after which it increased by $637 \%$ from day 6 to day 8 under the $200 \mathrm{mg} / \mathrm{L} \mathrm{Pb}$ treatment (Figure 2C). The rate of increase of $\mathrm{Pb}$ uptake in the skins of root necks increased gradually, initially by $9.3 \%$ from day 2 to day 4 , and finally $110 \%$ from day 6 to day 8 under the $200 \mathrm{mg} / \mathrm{L} \mathrm{Pb}$ treatment (Figure 2C). Pb concentrations in the skins of root necks increased over $19.5 \%$ at the first 4 days, by $33.2 \%$ in the next 2 days, after which there was a smaller increase (24.3\%) under the $500 \mathrm{mg} / \mathrm{L} \mathrm{Pb}$ treatment (Figure 2B). $\mathrm{Pb}$ concentrations in true roots increased by $204 \%$ during the first 4 days, and then by a much smaller increase of $1.2 \%$, after which it increased by $13.8 \%$ under the $200 \mathrm{mg} / \mathrm{L} \mathrm{Pb}$ treatment (Figure 2C).

$\mathrm{Pb}$ concentrations in root neck flesh showed a similar trend to that of true root flesh, although the scale of change was different (Figures 2B,C). However, the increased trend in the true roots under $500 \mathrm{mg} / \mathrm{L} \mathrm{Pb}$ treatment was opposite of $200 \mathrm{mg} / \mathrm{L}$ $\mathrm{Pb}$ treatment (Figures $\mathbf{2 B}, \mathbf{C}$ ). $\mathrm{Pb}$ concentrations in the root head decreased by $15.1 \%$, in the first 4 days, and then increased by $10.3 \%$ in the next 2 days, finally increasing by $202 \%$ in the last 2 days, under the $200 \mathrm{mg} / \mathrm{L} \mathrm{Pb}$ treatment. However, under $500 \mathrm{mg} / \mathrm{L} \mathrm{Pb}$ treatment, $\mathrm{Pb}$ concentrations in root head increased by $4.3 \%$ in the first 4 days, then by $47.2 \%$ in the next 2 days, and finally by $49.4 \%$ in the last 2 days. $\mathrm{Pb}$ concentration in
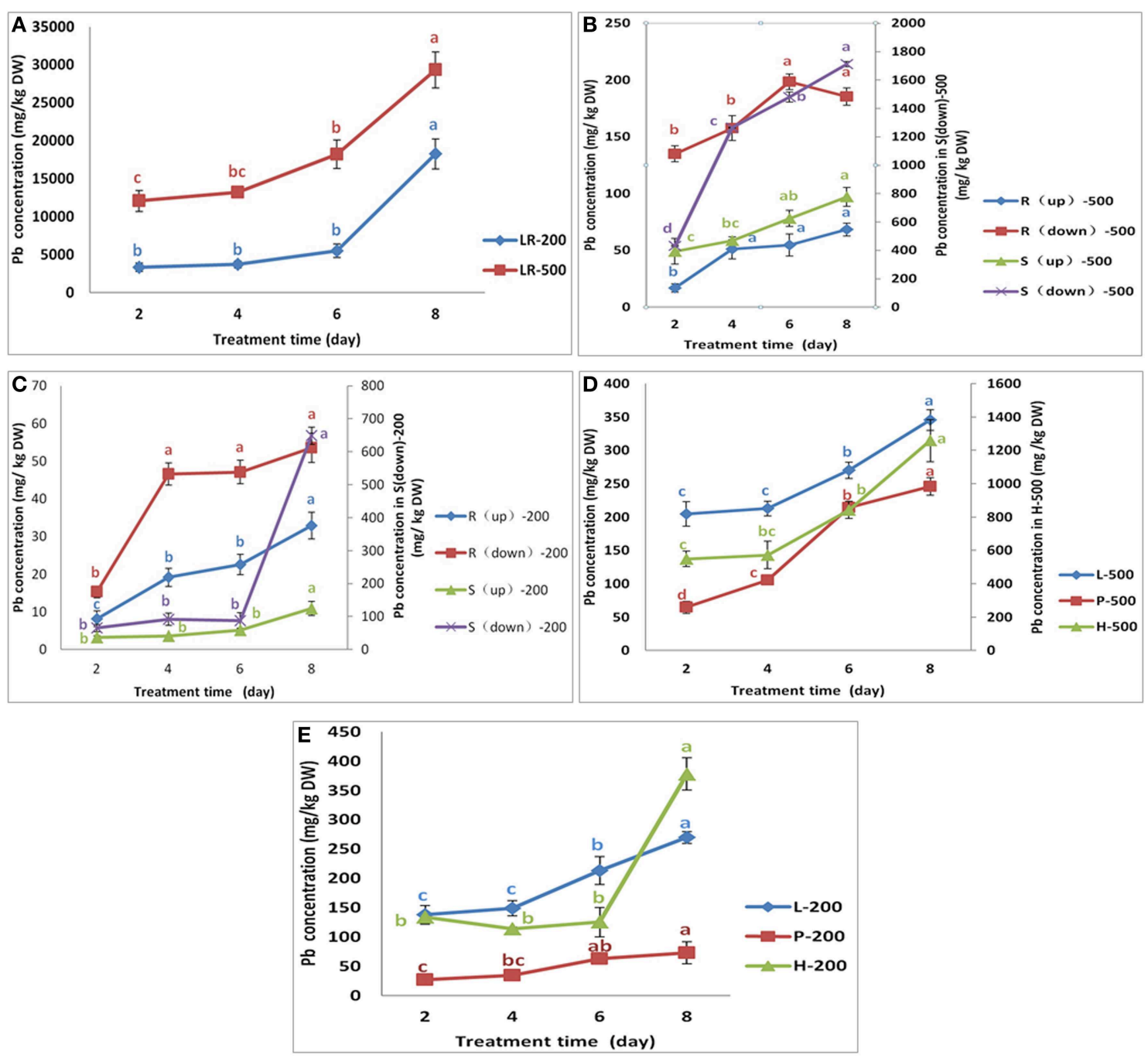

FIGURE 2 | Variation in the $\mathrm{Pb}$ concentration in different parts of NAU-XHT. Panel (A) represents the Pb concentration in lateral roots (LR). LR-200 and LR-500 were lateral roots treated with $200 \mathrm{mg} / \mathrm{L}$ and $500 \mathrm{mg} / \mathrm{L} \mathrm{Pb}\left(\mathrm{NO}_{3}\right)_{2}$, respectively. Panels $(\mathbf{B}, \mathbf{C})$ represent the $\mathrm{Pb}$ concentration in root flesh and skin(S) treated with $500 \mathrm{mg} / \mathrm{L}$ and $200 \mathrm{mg} / \mathrm{L} \mathrm{Pb}\left(\mathrm{NO}_{3}\right)_{2}$, respectively. $\mathrm{R}(\mathrm{up})-500$ and $\mathrm{S}$ (up)-500 were root neck and skin; $R($ down)-500 and $S($ down)-500 were true root and skin;
$R$ (up)-200 and S (up)-200 were root neck and skin; $R$ (down)-200, and S(down)-200 were true root and skin. Panel (D) L-500, P-500, and H-500 were leaves $(\mathrm{L})$, petioles $(\mathrm{P})$, and root heads $(\mathrm{H})$ treated with $500 \mathrm{mg} / \mathrm{L}$ $\mathrm{Pb}\left(\mathrm{NO}_{3}\right)_{2}$. Panel (E) L-200, P-200, and $\mathrm{H}-200$ were leaves, petioles, and root heads treated with $200 \mathrm{mg} / \mathrm{L} \mathrm{Pb}\left(\mathrm{NO}_{3}\right)_{2}$. Data are the mean $\pm \mathrm{SE}$ $(n=3)$ and different letters (lowercase) indicate significant differences at $P<0.05$. 
petioles increased by $30.4 \%$ and $63.6 \%$ in the first 4 days, then by $81.59 \%$ and $103 \%$ in the next 2 days, and finally by $15.2 \%$ and $14.81 \%$ in the last 2 days under $\mathrm{Pb}$ treatments of 200 and $500 \mathrm{mg} / \mathrm{L}$ (Figures 2D,E). The concentration of $\mathrm{Pb}$ in leaves of the NAU-XHT under the $200 \mathrm{mg} / \mathrm{L}$ treatment showed a similar trend to that of petioles. However, the leaf $\mathrm{Pb}$ concentrations increased by $4.0 \%$ in the first 4 days, then by $27 \%$ in the next 2 days, and by $27.9 \%$ in the last 2 days under the $500 \mathrm{mg} / \mathrm{L} \mathrm{Pb}$ treatment.

\section{Pb Translocation in Radish}

Translocation factors (TFs) are usually used to evaluate the capacity of a plant to translocate HMs from underground to aboveground. There were large differences in the TFs between lines. TFs ranged from 0.049 to 0.172 in the NAU-XLM under $\mathrm{Pb}$ treatments of 200 and $500 \mathrm{mg} / \mathrm{L}$ (Table 1). The TFs of the NAUXHT ranged from 0.018 to 0.048 under 200 and $500 \mathrm{mg} / \mathrm{L} \mathrm{Pb}$ treatments (Table 1 ). $\mathrm{Pb}$ was mostly concentrated in the underground parts, and only a small amount of $\mathrm{Pb}$ was translocated to the aboveground parts. The TFs of the NAU-XHT under Pb treatments of 200 and $500 \mathrm{mg} / \mathrm{L}$ showed a similar trend to those of the NAU-XLM. The TFs of both lines decreased from the second day to the fourth day, and then increased from the fourth day to the sixth day before decreasing again in the last 2 days.

With increasing treatment concentration, the TFs of leaves and petioles in both lines showed a downward trend except on the eighth day when TFs increased. Under the $200 \mathrm{mg} / \mathrm{L} \mathrm{Pb}$ treatment, the TFs of leaves in both lines showed a downward trend with increasing treatment duration. Under the $200 \mathrm{mg} / \mathrm{L}$ $\mathrm{Pb}$ treatment, the TFs of petioles in the NAU-XHT increased in the first few days and then declined slightly, the opposite trend to TFs in petioles of the NAU-XLM. Under the $500 \mathrm{mg} / \mathrm{L} \mathrm{Pb}$ treatment, TFs in the leaves of the NAU-XLM showed a similar trend to that of TFs in the aboveground parts of the NAU-XLM, and the TFs rose in the petioles of both lines. This observation indicated that there were differences in the capacity to translocate $\mathrm{Pb}$ between lines, and that the $\mathrm{Pb}$ concentration in both underground and aboveground parts increased with increasing treatment concentration and duration, but the proportion of the increase between the two parts was different.

\section{Chemical Forms of Pb within Radish}

The $\mathrm{Pb}$ extracted by $2 \% \mathrm{HAC}, 0.6 \mathrm{~mol} / \mathrm{L} \mathrm{HCl}$, and $1 \mathrm{~mol} / \mathrm{L} \mathrm{NaCl}$ were the predominant chemical forms of $\mathrm{Pb}$, representing 89.9699.30\% of the total $\mathrm{Pb}$ in different tissues of the NAU-XLM (Figure 3; Supplementary Table 3). In the lateral roots, the concentration of $\mathrm{Pb}$ extracted by $2 \% \mathrm{HAC}$ was greatest (42.50$51.97 \%$ ), followed by $1 \mathrm{~mol} / \mathrm{L} \mathrm{NaCl}$ and lastly $0.6 \mathrm{~mol} / \mathrm{L} \mathrm{HCl}$; in the skins, the concentration of $\mathrm{Pb}$ extracted with $0.6 \mathrm{~mol} / \mathrm{L} \mathrm{HCl}$ was the greatest, representing $60.28 \%$ and $44.93 \%$ under $\mathrm{Pb}$ treatments of 200 and $500 \mathrm{mg} / \mathrm{L}$, but the proportion of $2 \%$ HACextractable and $1 \mathrm{~mol} / \mathrm{L} \mathrm{NaCl}$-extractable $\mathrm{Pb}$ became increasingly greater with increasing $\mathrm{Pb}$ treatment. In the roots and leaves of the NAU-XLM, the concentration of $\mathrm{Pb}$ extracted by $0.6 \mathrm{~mol} / \mathrm{L}$ $\mathrm{HCl}$ was greatest $(55.60-63.46 \%$ in roots and $56.32-67.71 \%$ in leaves (Figure 3). However, chemical forms of $\mathrm{Pb}$ extracted by $\mathrm{d}$ $\mathrm{H}_{2} \mathrm{O}$ increased with enhancing $\mathrm{Pb}$ treatment strength (Figure 3). The $\mathrm{Pb}$ extracted by $2 \% \mathrm{HAC}, 0.6 \mathrm{~mol} / \mathrm{L} \mathrm{HCl}$, and $1 \mathrm{~mol} / \mathrm{L} \mathrm{NaCl}$ were the predominant chemical forms of $\mathrm{Pb}$ in all treatment levels in the lateral roots and skins of NAU-XHT, representing $94.21-96.23 \%$ (lateral roots) and $90.97-93.60 \%$ (skins) of the total $\mathrm{Pb}$ (Figure 3). In the roots and leaves of the NAU-XHT, $\mathrm{Pb}$ concentrations extracted by $\mathrm{d}-\mathrm{H}_{2} \mathrm{O}$ enhanced with increased $\mathrm{Pb}$ treatment strength; in addition, the proportion of $0.6 \mathrm{~mol} / \mathrm{L}$ $\mathrm{HCl}$-extractable $\mathrm{Pb}, 1 \mathrm{~mol} / \mathrm{L} \mathrm{NaCl}$-extractable $\mathrm{Pb}$ and $\mathrm{d}-\mathrm{H}_{2} \mathrm{O}$ extractable $\mathrm{Pb}$ was the highest, representing 85.84-92.98\% of the total $\mathrm{Pb}$ (Figure 3). Moreover, $\mathrm{Pb}$ concentration in taproots without skin and aboveground increased with enhancing $\mathrm{d}-\mathrm{H}_{2} \mathrm{O}$ extractable $\mathrm{Pb}$ concentration (Figure 3).

TABLE 1 | Translocation factors (TFs) in four time periods under two Pb treatments*.

\begin{tabular}{|c|c|c|c|c|c|}
\hline \multirow{2}{*}{$\begin{array}{l}\text { Cultivars } \\
\text { Treatment (mg/L) }\end{array}$} & & \multicolumn{2}{|c|}{ NAU-XLM } & \multicolumn{2}{|c|}{ NAU-XHT } \\
\hline & & 200 & 500 & 200 & 500 \\
\hline \multirow[t]{4}{*}{ Leaf } & $2 d$ & $0.143 \pm 0.016 a^{\star \star}$ & $0.074 \pm 0.018 a$ & $0.039 \pm 0.005 a$ & $0.015 \pm 0.002 a$ \\
\hline & $4 d$ & $0.060 \pm 0.006 b$ & $0.032 \pm 0.004 b$ & $0.038 \pm 0.001 a$ & $0.013 \pm 0.001 a$ \\
\hline & $6 d$ & $0.056 \pm 0.005 b$ & $0.040 \pm 0.004 b$ & $0.037 \pm 0.002 a$ & $0.013 \pm 0.002 a$ \\
\hline & $8 d$ & $0.046 \pm 0.013 b$ & $0.035 \pm 0.001 b$ & $0.014 \pm 0.001 b$ & $0.010 \pm 0.001 a$ \\
\hline \multirow[t]{4}{*}{ Petiole } & $2 d$ & $0.029 \pm 0.007 a$ & $0.016 \pm 0.001 a$ & $0.008 \pm 0.001 \mathrm{ab}$ & $0.005 \pm 0.000 c$ \\
\hline & $4 d$ & $0.022 \pm 0.000 a$ & $0.017 \pm 0.002 a$ & $0.009 \pm 0.001 a$ & $0.007 \pm 0.000 b$ \\
\hline & $6 d$ & $0.032 \pm 0.003 a$ & $0.019 \pm 0.003 a$ & $0.011 \pm 0.002 a$ & $0.010 \pm 0.001 a$ \\
\hline & $8 d$ & $0.030 \pm 0.007 a$ & $0.021 \pm 0.010 a$ & $0.004 \pm 0.001 b$ & $0.007 \pm 0.001 b$ \\
\hline \multirow[t]{4}{*}{ Above-ground } & $2 d$ & $0.172 \pm 0.023 a$ & $0.090 \pm 0.017 a$ & $0.047 \pm 0.006 a$ & $0.020 \pm 0.002 a$ \\
\hline & $4 d$ & $0.082 \pm 0.006 b$ & $0.049 \pm 0.003 b$ & $0.043 \pm 0.005 a$ & $0.020 \pm 0.000 a$ \\
\hline & $6 d$ & $0.085 \pm 0.004 b$ & $0.059 \pm 0.007 a b$ & $0.048 \pm 0.004 a$ & $0.023 \pm 0.002 a$ \\
\hline & $8 d$ & $0.073 \pm 0.020 b$ & $0.055 \pm 0.008 b$ & $0.018 \pm 0.002 b$ & $0.018 \pm 0.002 a$ \\
\hline
\end{tabular}

${ }^{*} T F=C_{i} / C_{r}, C_{i}$ is the $P b$ concentration in the aboveground tissues and $C_{r}$ is the $P b$ concentration in the roots.

${ }^{* \star}$ Data are the means of three replicates ( \pm SE). Different letters indicate significant differences according to Duncan's test at $P<0.05$ (lowercase). 


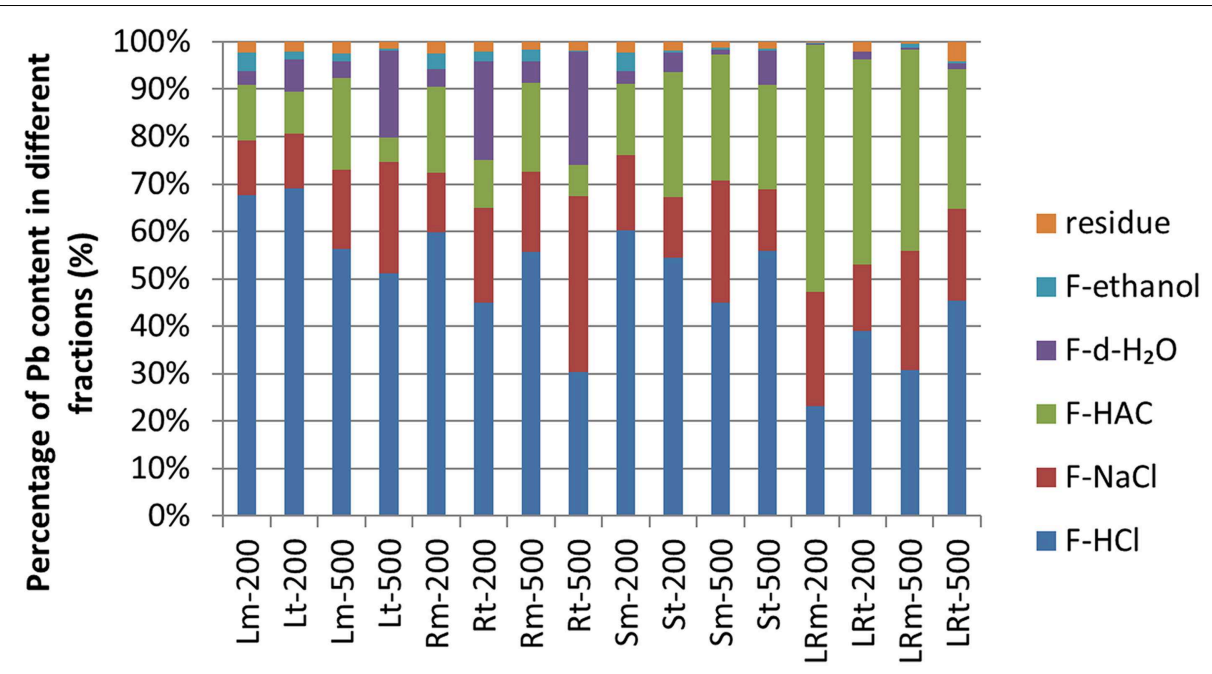

Different parts of radish under two $\mathrm{Pb}$ treatments

FIGURE 3 | Different chemical forms of $\mathrm{Pb}$ and its distribution in different tissues of radish. Lm-200, Rm-200, Sm-200, and LRm-200 were leaves $(\mathrm{L})$, roots $(\mathrm{R})$, skins $(\mathrm{S})$, and lateral roots $(\mathrm{LR})$ of $N A U-X L M$ treated with $200 \mathrm{mg} / \mathrm{L} \mathrm{Pb}\left(\mathrm{NO}_{3}\right)_{2}$; Lm-500, Rm-500, Sm-500, and LRm-500 were leaves, roots, skins, and lateral roots of the NAU-XLM treated with $500 \mathrm{mg} / \mathrm{L} \mathrm{Pb}\left(\mathrm{NO}_{3}\right)_{2}$; Lt-200, Rt-200, St-200, and LRt-200 were leaves, roots, skins, and lateral roots of the NAU-XHT treated with $200 \mathrm{mg} / \mathrm{L} \mathrm{Pb}\left(\mathrm{NO}_{3}\right)_{2}$; Lt-500, Rt-500, St-500, and LRt-500 were leaves, roots, skins, and lateral roots of NAU-XHT treated with
$500 \mathrm{mg} / \mathrm{L} \mathrm{Pb}\left(\mathrm{NO}_{3}\right)_{2}$. Residue represents $\mathrm{Pb}$ concentration in residue; F-ethanol represents ethanol-extractable form, inorganic $\mathrm{Pb}$ including nitrate/nitrite, chloride; $\mathrm{F}-\mathrm{dH}_{2} \mathrm{O}$ extracting water-soluble $\mathrm{Pb}$ of organic acid and $\mathrm{Pb}\left(\mathrm{PO}_{4}\right)_{2}$; F-HAC represents $\mathrm{HAC}$ - extractable form, undissolved lead phosphate including $\mathrm{PbHPO}_{4}$ and $\mathrm{Pb}_{3}\left(\mathrm{PO}_{4}\right)_{2} ; \mathrm{F}-\mathrm{NaCl}$ extracting pectates, protein integrated $\mathrm{Pb} ; \mathrm{F}-\mathrm{HCl}$ represents $\mathrm{HCl}$ extractable form, extracting lead oxalic. All abbreviations ending with "m" refer to NAU-XLM and "t" to NAU-XHT, "R" to root and "LR' to lateral root, "S" to skin and "L" to leaf.

\section{Subcellular Distribution of $\mathrm{Pb}$ in Radish}

$\mathrm{Pb}$ concentrations in the different subcellular components of various radish tissues increased with enhanced $\mathrm{Pb}$ treatment strength (Figure 4; Supplementary Table 4). In lateral roots, most $\mathrm{Pb}$ was present in the cell wall fraction and nucleus and chloroplasts fraction, representing $87.62-93.76 \%$ and $93.72-95.29 \%$ of $\mathrm{Pb}$ in the NAU-XLM and NAU-XHT, respectively (Figure 4A). In skins, a large proportion of $\mathrm{Pb}$ was bound to the cell wall fraction, representing $54.44-77.94 \%$ and $46.22-77.59 \%$ of $\mathrm{Pb}$ in the NAU-XLM and NAU-XHT, respectively (Figure 4B). However, under the $200 \mathrm{mg} / \mathrm{L} \mathrm{Pb}$ treatment, a large amount of $\mathrm{Pb}$ also accumulated in soluble components containing ribosomes, representing $23.35 \%$ and $29.39 \%$ of total $\mathrm{Pb}$ in the skins of the NAU-XLM and NAU-XHT, respectively (Figure 4B). In roots, most $\mathrm{Pb}$ was localized in the cell wall fraction and soluble components containing ribosomes, representing 74.55-74.89\% and $76.52-77.10 \%$ of $\mathrm{Pb}$, in the NAU-XLM and NAU-XHT, respectively. The proportion of $\mathrm{Pb}$ in the cell wall fraction increased, but the proportion in soluble components containing ribosomes decreased with enhancing $\mathrm{Pb}$ treatment strength (Figure 4C). A similar result was found in leaves, the proportions of $\mathrm{Pb}$ in the cell wall fraction and soluble components containing ribosomes were $71.17-74.61 \%$ and $69.05-80.46 \%$ in the NAU-XLM and NAU-XHT, respectively (Figure 4C). A greater proportion of $\mathrm{Pb}$ was bound to the cell wall fraction in the NAU-XHT than that in the NAU-XLM, and a smaller proportion of $\mathrm{Pb}$ was localized in the soluble fraction of the NAU-XHT than that in the NAU-XLM.

\section{Ultrastructural Localization of $\mathrm{Pb}$ in Cells of Radish}

To show the $\mathrm{Pb}$ particles in subcellular fractions visibly, the roots and lateral roots of NAU-XLM under the $500 \mathrm{mg} / \mathrm{L} \mathrm{Pb}$ treatment were sampled for TEM analysis. Transverse sections of radish roots and lateral roots observed by TEM revealed many $\mathrm{Pb}$ particles in cell walls (Figures 5A,C, 6E) and in the intercellular space (Figures 5B-D,6A,B) of both taproot and lateral root cells. Large amounts of $\mathrm{Pb}$ precipitates were distributed mainly around the surface of the vacuole membrane (Figure 6D) and lumen (Figure 6C). Precipitates of $\mathrm{Pb}$ were also found in the plasma lemma (Figures 6B, F), cytoplasm (Figure 6G), and epidermis (Figure 6H).

\section{Discussion}

\section{Uptake and Transport of $\mathrm{Pb}$ in Radish}

Recently, with increasing concern about the HM pollution and safe vegetable production, there have been many studies on the uptake, accumulation, and translocation of HMs in vegetable crops. Radish, an important vegetable crop, can uptake and accumulate $\mathrm{HMs}$ including $\mathrm{Pb}$ in the root (El-Beltagi and Mohamed, 2010; Inoue et al., 2013). Our study indicated that the lateral roots accumulated a large proportion of $\mathrm{Pb}$, representing 66.2991.56\%, and $82.35-92.04 \%$ of Pb uptake in the NAU-XLM and NAU-XHT, respectively. The results also show that lateral roots of the NAU-XLM are enriched with a large amount of $\mathrm{Pb}$ when they are exposured to $\mathrm{Pb}$ in the solution for the first time (Figure 1A), 
A

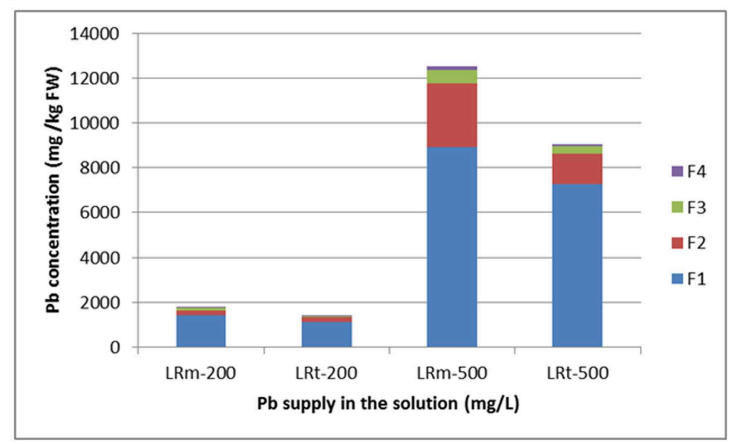

B

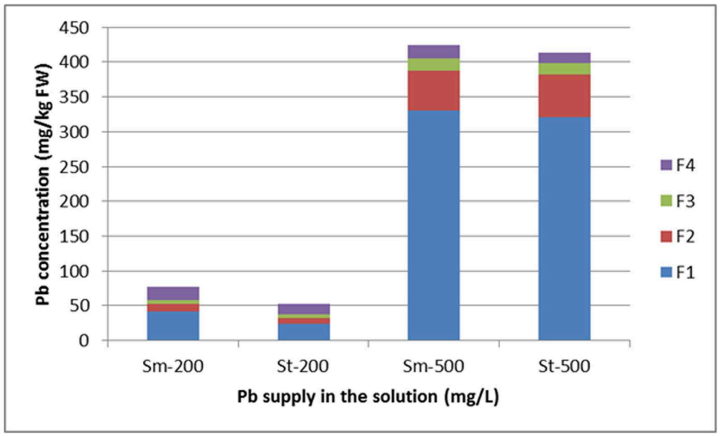

C

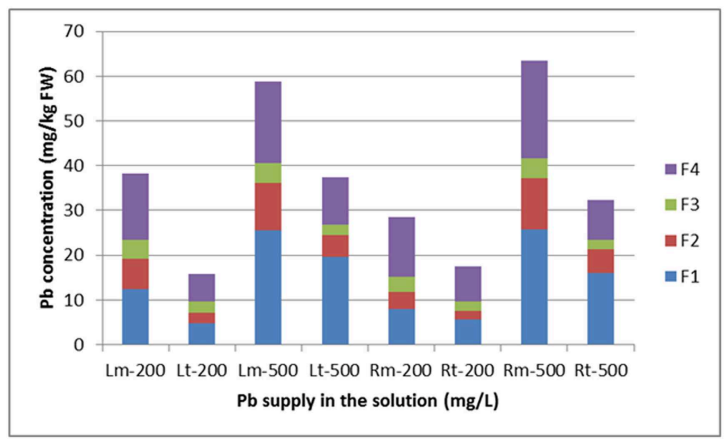

FIGURE 4 | Subcellular distribution of $\mathrm{Pb}$ and its stacking proportion in lateral roots $(A)$, root skin $(B)$, and leaves and roots (C) of radish. LRm-200 and LRt-200 as well as LRm-500 and LRt-500 represent lateral root treated with 200 and $500 \mathrm{mg} / \mathrm{L} \mathrm{Pb}\left(\mathrm{NO}_{3}\right)_{2}$, respectively; Sm-200 and St-200 as well as Sm-500 and St-500 represent root skin treated with 200 and $500 \mathrm{mg} / \mathrm{L} \mathrm{Pb}\left(\mathrm{NO}_{3}\right)_{2}$, respectively. Lm-200 and Lt-200 as well as Rm-200 and Rt-200 represent leave and root flesh treated with $200 \mathrm{mg} / \mathrm{L} \mathrm{Pb}\left(\mathrm{NO}_{3}\right)_{2}$, respectively; Lm-500 and Lt-500 as well as Rm-500 and Rt-500 represent leaves and roots treated with $500 \mathrm{mg} / \mathrm{L} \mathrm{Pb}\left(\mathrm{NO}_{3}\right)_{2}$, respectively. $\mathrm{F} 1, \mathrm{~F} 2$, F3, and F4 represent the fraction of cell wall, nucleus and chloroplasts, mitochondria, and soluble components containing ribosomes, respectively. All abbreviations ending with "m" refer to NAU-XLM and "t" to NAU-XHT, "R" to root, and "LR" to lateral root, "S" to skin and "L" to leaf. then the rate of $\mathrm{Pb}$ enrichment decreased, after which there is an increase again with increasing treatment duration. However, compared with the NAU-XLM, the uptake of $\mathrm{Pb}$ in lateral roots of the NAU-XHT was smaller for the first stage, and then the rate of $\mathrm{Pb}$ enrichment increased gradually with increasing treatment duration (Figure 2A). The skins accumulated a relatively larger portion of $\mathrm{Pb}(2.40-10.80 \%)$ than that of taproots without the skins $(0.44-1.56 \%)$ in the NAU-XHT. Moreover, the skins with lateral roots accumulated more $\mathrm{Pb}(1.44-7.88 \%)$ than the smooth skins without lateral roots $(0.63-2.92 \%)$.

The root heads of radish also accumulated high levels of $\mathrm{Pb}$ (1.90-3.95\%) in the NAU-XHT. Similar to many other studies (Liu et al., 2003; El-Beltagi and Mohamed, 2010; Inoue et al., 2013), most $\mathrm{Pb}$ was retained in underground tissues, and little was transported to aboveground parts, as demonstrated by TFs. The $\mathrm{Pb}$ in aboveground parts may have been absorbed from the treatment solution or it may have been transported from underground parts. Generally, the $\mathrm{Pb}$ concentration in leaves was greater than that in petioles under $\mathrm{Pb}$ treatments of 200 and $500 \mathrm{mg} / \mathrm{L}$, but the $\mathrm{Pb}$ concentration in petioles increased faster than in leaves with an increase in treatment duration and concentration. Previous studies have demonstrated that metal-tolerant plants accumulated higher concentrations of HMs in roots and lower concentrations in shoots compared with the non-metal-tolerant plants (Xu et al., 2011; Lu et al., 2014). Our results also indicated that this was an important tolerance mechanism of radish. In this study, radish lateral roots initially took up a large amount of $\mathrm{Pb}$, and then a portion of the $\mathrm{Pb}$ was absorbed and a little was transported upward. Radish skins accumulated a lot of $\mathrm{Pb}$, while roots without skin showed minimum uptake of $\mathrm{Pb}$.

\section{Chemical Forms of Lead in Radish}

Different chemical forms affect the degree of toxicity and migration of HMs in plants (Fu et al., 2011; Weng et al., 2012). For instance, water-soluble $\mathrm{Pb}$ in inorganic form (extracted by $80 \%$ ethanol) and in organic form (extracted by $\mathrm{d}-\mathrm{H}_{2} \mathrm{O}$ ) exhibited higher chances of translocation. In these forms, $\mathrm{Pb}$ can easily penetrate into the cytoplasm and attach to the cell organelles as well as intercellular spaces in soluble fraction, having a more harmful effect on plant cells in comparison with the undissolved $\mathrm{Pb}$-phosphate (extracted by $2 \% \mathrm{HAC}$ ) and $\mathrm{Pb}$ oxalate (extracted by $0.6 \mathrm{~mol} / \mathrm{L} \mathrm{HCl}$ ) (Xu et al., 2011). The majority of $\mathrm{Pb}$ in radish tissues was integrated undissolved $\mathrm{Pb}$ oxalate (extracted by 

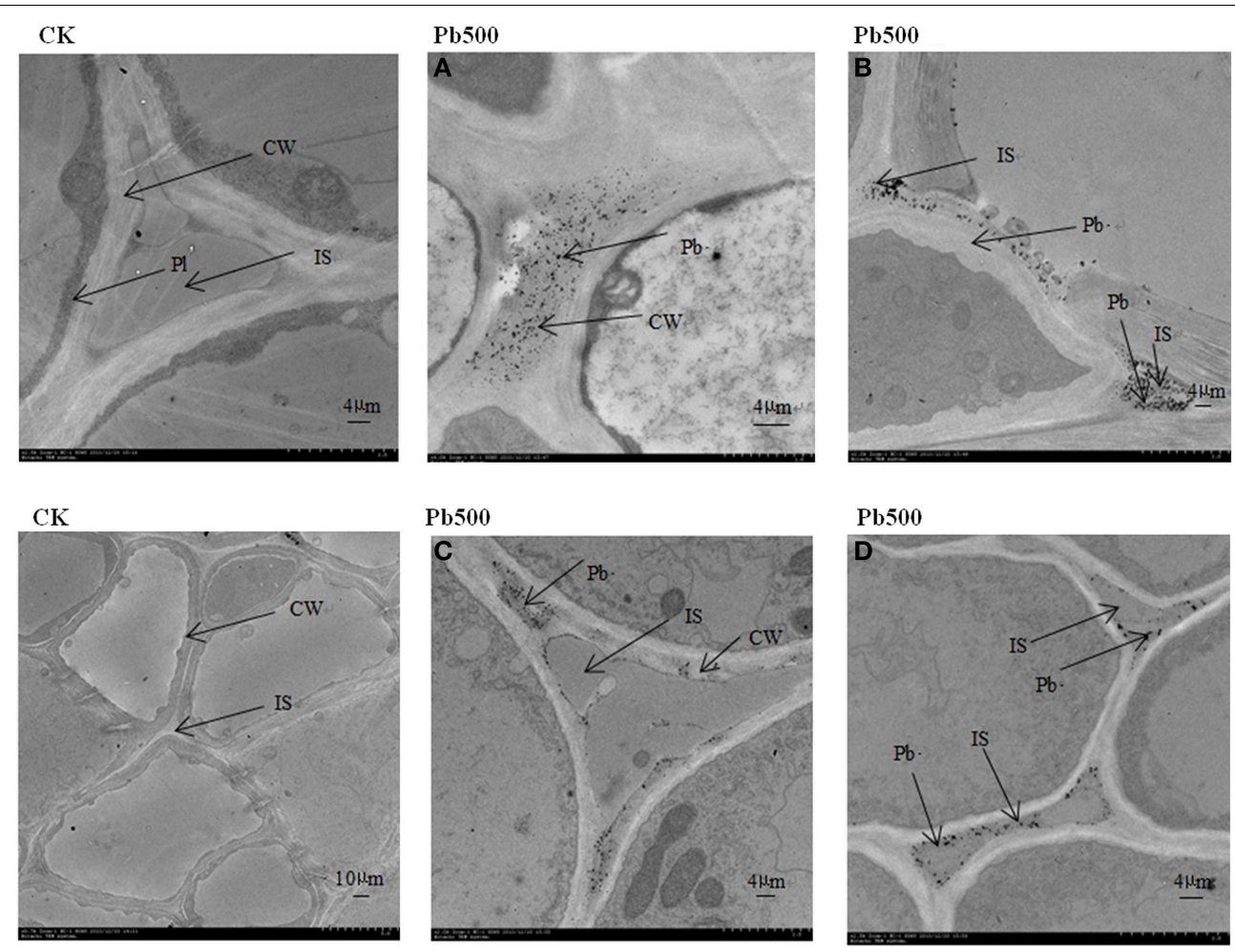

FIGURE 5 | Ultrastructure of transverse sections of lateral roots in NAU-XLM under $\mathbf{5 0 0} \mathbf{~ m g} / \mathbf{L ~ P b}$ treatment. Electron-dense particles were localized in CW, cell wall $\mathbf{( A , C )}$ and IS, intercellular space (B,D). PI refers to plasmalemma.

$0.6 \mathrm{~mol} / \mathrm{L} \mathrm{HCl}$ ), protein and pectates (extracted by $1 \mathrm{~mol} / \mathrm{L} \mathrm{NaCl}$ ) and $\mathrm{Pb}$-phosphate complexes (extracted by $2 \% \mathrm{HAC}$ ). Moreover, in various tissues under $\mathrm{Pb}$ treatment, the NAU-XHT, a relatively low accumulation genotype, had a higher proportion of $\mathrm{Pb}$ in water-soluble forms, and a lower proportion (74.11-96.24 \%) of undissolved $\mathrm{Pb}$ oxalate, protein and pectates, and $\mathrm{Pb}$-phosphate complexes forms than the NAU-XLM (89.96-99.30\%), a relatively high accumulation genotype. The higher concentration of undissolved $\mathrm{Pb}$ phosphate, pectates and protein integrated $\mathrm{Pb}$ and lower concentration of water-soluble $\mathrm{Pb}$ in the underground parts in plants may be a possible mechanism of tolerance to $\mathrm{Pb}$ toxicity in these relatively $\mathrm{Pb}$-tolerant genotypes.

\section{Subcellular Distribution and Location of Lead in Radish}

Cell compartmentalization and complexity, including cell wall deposition and vacuolar compartmentation play a significant role in HM detoxification, tolerance, and hyperaccumulation in plants (Wang et al., 2008; Fu et al., 2011). The cell wall is the first barrier preventing HMs from damaging plant cells. It contains mainly pectic acid, polysaccharides, and protein and provides plentiful $\mathrm{HM}$ ion exchange sites, which can fix $\mathrm{Pb}$ ions and restrict their movement across the cytomembrane (Inoue et al., 2013). In addition, $\mathrm{Pb}^{2+}$ binds to carboxyl groups which are possibly pectin compounds of cell walls (Inoue et al., 2013). The cell wall is the main binding site for various HM ions in plant species (Xu et al., 2012; Hou et al., 2013; Lu et al., 2014). However, when cell wall binding sites reach saturation, most intracellular HM ions are transported to vacuoles, and then chelated with citric acid, oxalic acid, and other organic acids, through which the HM ions are segregated (Kramer, 2000; Weng et al., 2012). In this study, a large portion of $\mathrm{Pb}$ was found to be stored in the cell wall fraction (32.07-80.40\%). Moreover, ultrastructural observation also revealed plentiful $\mathrm{Pb}$ deposits on the cell wall of roots and lateral roots. The soluble fraction, containing mainly vacuoles is the subdominant $\mathrm{HM}$ binding site.

We found a significant percentage of $\mathrm{Pb}$ stored in soluble components in the leaves and roots of both lines. Moreover, a higher proportion of $\mathrm{Pb}$ was bound on the cell wall fraction of the NAU-XHT than that of the NAU-XLM, and a lower proportion of $\mathrm{Pb}$ was localized in the soluble fraction of the NAU-XHT than that of the NAU-XLM. This study also indicated that a relatively high proportion of the cell wall fraction could prevent $\mathrm{Pb}$ from penetrating into the cell interior, resulting in the reduction of $\mathrm{Pb}$ concentration in soluble fractions. Qiu et al. (2011) also found that the cadmium (Cd) compartment functioned better in a low-Cd-accumulating cultivar compared with a highCd-accumulating cultivar of flowering cabbage. Previous studies have also showed that the proportion of $\mathrm{Cd}$ associated with organelles was much greater in leaves than in roots and stems, which probably result from the preferential accumulation of $\mathrm{Cd}$ in chloroplasts (Ramos et al., 2002; Wang et al., 2008). However, similar results were not found for Kandelia obovata (Weng et al., 2012) and in this study. Ultrastructural observation of roots and 

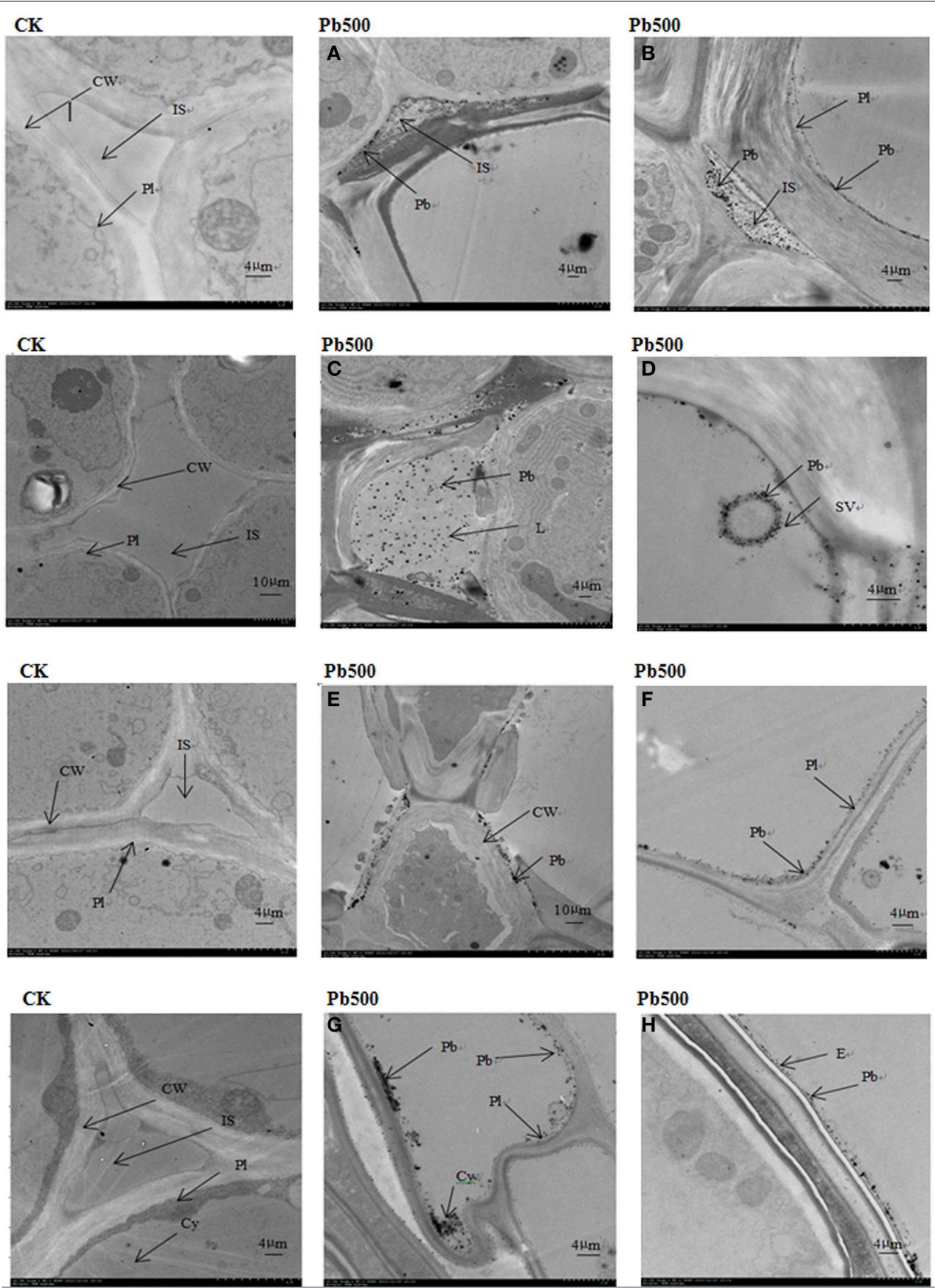

FIGURE 6 | Ultrastructure of transverse sections of roots in NAU-XLM under $\mathbf{5 0 0 ~} \mathbf{m g} / \mathbf{L ~ P b}$ treatment. Electron-dense particles were localized in IS, intercellular space (A,B); L, lumen (C); SV, small vacuole (D); CW, cell wall (E); PI, plasmalemma (F); Cy, cytoplasm (G); and E, epidermis (H).

lateral roots also indicated $\mathrm{Pb}$ deposited in intercellular spaces, on cell walls, in plasma lemma, lumina, and vacuoles, which was in agreement with previous studies (Malecka et al., 2008; El-Beltagi and Mohamed, 2010; Inoue et al., 2013).

With the development of industry and the expansion of population, the anthropogenic $\mathrm{Pb}$ in soils has become one of the most toxic HMs, which may cause potential health risks to human beings and animals through the food chain. Therefore, minimizing the intake of $\mathrm{Pb}$ from vegetable crops and reducing $\mathrm{Pb}$ risks to human health is becoming a major worldwide ecological concern. In the present study, to investigate the mechanism of $\mathrm{Pb}$ accumulation and translocation in radish plant responding to the $\mathrm{Pb}$ stress, we selected the hydroponic culture, which allows us to control the environmental and stress conditions 


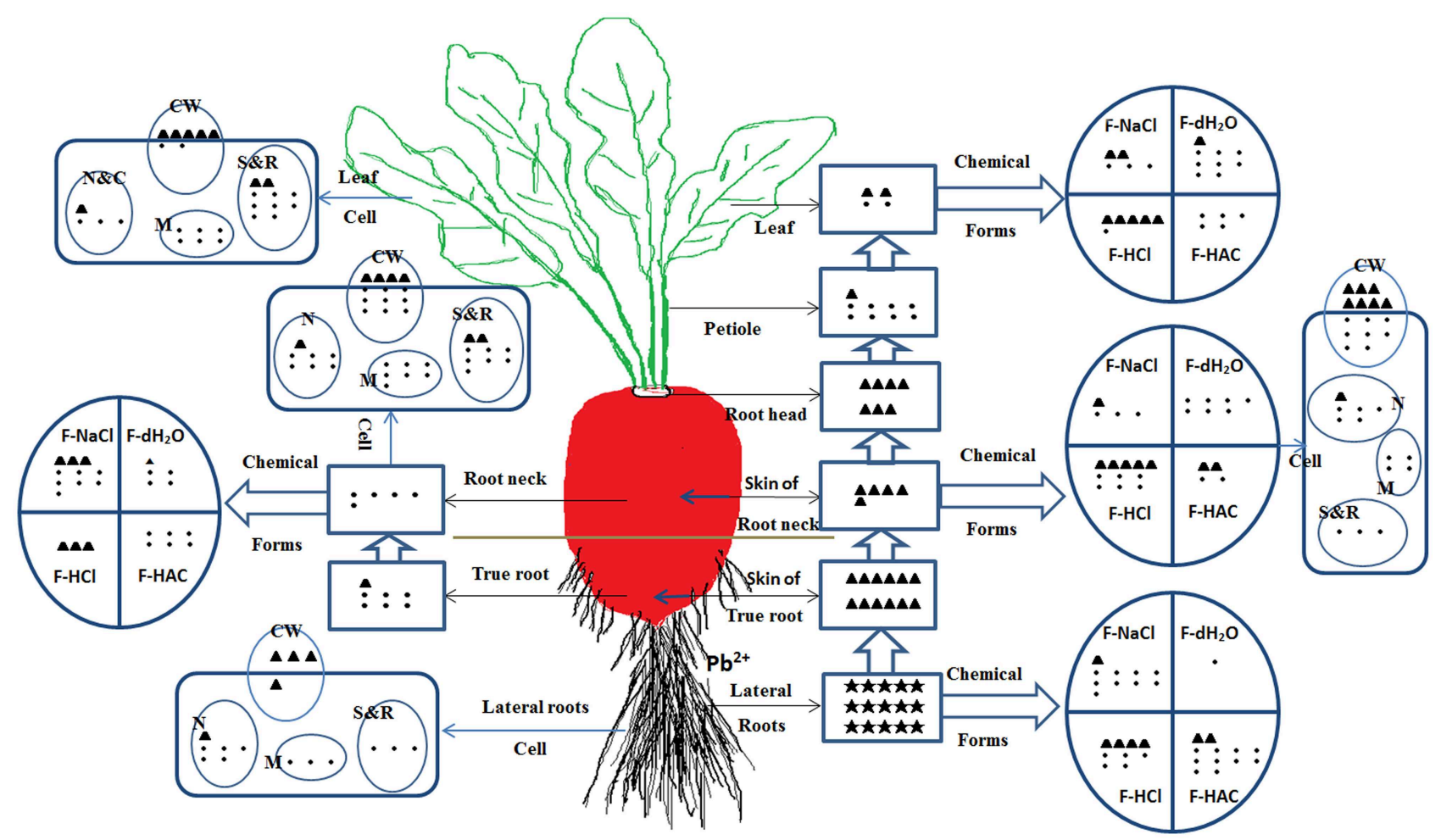

FIGURE 7 | The uptake, translocation and distribution of $\mathrm{Pb}$ in radish line NAU-XHT under $500 \mathrm{mg} / \mathrm{L} \mathrm{Pb}$ treatment. Symbol "•" represents basic concentration unit, " $\mathbf{\Delta}$ " represents 10 -fold of the unit, " $\star$ " represents 100 -fold of the unit. The number of unit symbol refers to $\mathrm{Pb}$ relative concentration for tissue levels, chemical forms, and subcellular fractions from various plant parts. $\mathrm{F}-\mathrm{HCl}$ represents
$\mathrm{HCl}$-extractable form, lead oxalic; F-HAC represents HAC-extractable form, undissolved lead phosphate including $\mathrm{PbHPO}_{4}$ and $\mathrm{Pb}_{3}\left(\mathrm{PO}_{4}\right)_{2}$; $\mathrm{F}-\mathrm{NaCl}$ extracting pectates, protein integrated $\mathrm{Pb} ; \mathrm{F}-\mathrm{dH}_{2} \mathrm{O}$ extracting water-soluble $\mathrm{Pb}$ of organic acid, and $\mathrm{Pb}\left(\mathrm{PO}_{4}\right)_{2}$. CW (Cell wall), $\mathrm{N}$ (Nucleus), M (Mitochondria), N\&C (Nucleus and Chloroplasts fraction), S\&R (Soluble fraction and Ribosome). easily and effectively. HM accumulation in plants varied with plant species and genotypes, types of HMs, the uptake capacity and translocation efficiency of roots, and growth medium conditions (soil and nutrition solution) (Liu et al., 2010; Zheng et al., 2011). Therefore, further studies including field-culture experiments with combined HM treatments in soils could be carried out to illustrate the mechanism of HM accumulation for safe vegetable production. In this study, we characterized $\mathrm{Pb}$ transport, ultrastructural localization, and distribution of chemical forms of $\mathrm{Pb}$ in different tissues of radish plants with hydroponic culture (Figure 7). The results indicated relatively low TFs and high tolerance to $\mathrm{Pb}$ in radish. Most $\mathrm{Pb}$ was retained in lateral roots and skins thus restricting translocation to inner parts of the taproot and aboveground plant tissues. When the $\mathrm{Pb}$ was transported to inner tissues, it was mostly associated with undissolved chemical forms which have minimal motility. At a subcellular level, a large amount of $\mathrm{Pb}$ was deposited in intercellular space, bound to cell walls and stored in vacuoles, thereby reducing free $\mathrm{Pb}$ ions in the cytoplasm. These results could provide a solid foundation for further dissecting the mechanism of $\mathrm{Pb}$ accumulation, and facilitating development of low- $\mathrm{Pb}$-content cultivar in root vegetable crops.

\section{Acknowledgments}

This work was in part supported by grants from the Natural Science Foundation of Jiangsu Province (BK20140706), NSF of China (31372064, 31171956), Key Technology R\&D Program of Jiangsu Province (BE2013429), JASTIF [CX (12)2006, CX(13)2007] and the PAPD.

\section{Supplementary Material}

The Supplementary Material for this article can be found online at: http://journal.frontiersin.org/article/10.3389/fpls.2015. 00293/abstract 


\section{References}

Abou-Shanab, R., Ghanem, N., Ghanem, K., and Al-Kolaibe, A. (2007). Phytoremediation potential of crop and wild plants for multi-metal contaminated soils. Res. J. Agr. Biol. Sci. 3, 370-376.

Alexander, P. D., Alloway, B. J., and Dourado, A. M. (2006). Genotypic variations in the accumulation of $\mathrm{Cd}, \mathrm{Cu}, \mathrm{Pb}$ and $\mathrm{Zn}$ exhibited by six commonly grown vegetables. Environ. Pollut. 144, 736-745. doi: 10.1016/j.envpol.2006. 03.001

Capdevila, F., Nadal, M., Schuhmacher, M., and Domingo, J. L. (2003). Intake of lead and cadmium from edible vegetables cultivated in Tarragona Province, Spain. Trace Elem. Electrolytes. 20, 256-261. doi: 10.5414/TEP20256

Caussy, D., Gochfeld, M., Gurzau, E., Neagu, C., and Ruedel, H. (2003). Lessons from case studies of metals: investigation exposure, bioavailability, and risk. Ecotoxicol. Environ. Saf. 56, 45-51. doi: 10.1016/S0147-6513(03) 00049-6

Cui, D. J., and Zhang, Y. L. (2004). Current situation of soil contamination by heavy metals and research advances on the remediation techniques. Chin. J. Soil Sci. 35, 366-370.

Eick, M. J., Peak, J. D., Brady, P. V., and Pesek, J. D. (1999). Kinetics of lead adsorption and desorption on goethite: residence time effect. Soil Sci. 164, 28-39. doi: 10.1097/00010694-199901000-00005

El-Beltagi, H. S., and Mohamed, A. A. (2010). Changes in non protein thiols, some antioxidant enzymes activity and ultrastructural alteration in radish plant (Raphanus sativus L.) grown under lead toxicity. Not. Bot. Hort. Agrobot. Cluj. $38,76-85$.

Fu, X. P., Dou, C. M., Chen, Y. X., Chen, X. C., Shi, J. Y., Yu, M. G., et al. (2011). Subcellular distribution and chemical forms of cadmium in Phytolacca americana L. J. Hazard. Mater. 186, 103-107. doi: 10.1016/j.jhazmat.2010.10.122

Gidlow, D. A. (2004). Lead toxicity. Occup. Med. 54, 76-81. doi: 10.1093/occmed/kqh019

He, B., Yang, X. E., Ni, W. Z., Wei, Y. Z., and Ye, H. B. (2003). Pb uptake, accumulation, subcellular distribution in a $\mathrm{Pb}$-accumulation ecotype of Sedum alfredii (Hance). J. Zhejiang Univ. Sci. 4, 474-479. doi: 10.1631/jzus.2003.0474

Hou, M., Hu, C. J., Xiong, L., and Lu, C. (2013). Tissue accumulation and subcellular distribution of vanadium in Brassica juncea and Brassica chinensis. Microchem. J. 110, 575-578. doi: 10.1016/j.microc.2013.07.005

Inoue, H., Fukuoka, D., Tatai, Y., Kamachi, H. Y., Hayatsu, M., Ono, M., et al. (2013). Properties of lead deposits in cell walls of radish (Raphanus sativus) roots. J. Plant Res. 126, 51-61. doi: 10.1007/s10265-012-0494-6

Kramer, U. (2000). Cadmium for all meals-plants with an unusual appetite. New Phytol. 145, 1-3. doi: 10.1046/j.1469-8137.2000.00567.x

Li, X. Y., Liu, L. J., Wang, Y. G., Luo, G. P., Chen, X., Yang, X. L., et al. (2013). Heavy metal contamination of urban soil in an old industrial city (Shenyang) in Northeast China. Geoderma 192, 50-58. doi: 10.1016/j.geoderma.2012.08.011

Liu, J. G., Li, K. Q., Xu, J. K., Zhang, Z. J., Ma, T. B., Lu, X. L., et al. (2003). Lead toxicity, uptake, and translocation in different rice cultivars. Plant Sci. 165, 793-802. doi: 10.1016/S0168-9452(03)00273-5

Liu, J. G., Ma, X. M., Wang, M. X., and Sun, X. W. (2013). Genotypic differences among rice cultivars in lead accumulation and translocation and the relation with grain $\mathrm{Pb}$ levels. Ecotoxicol. Environ. Saf. 90, 35-40. doi: 10.1016/j.ecoenv.2012.12.007

Liu, W. T., Zhou, Q. X., Zhang, Y. L., and Wei, S. H. (2010). Lead accumulation in different Chinese cabbage cultivars and screening for pollution-safe cultivars. J. Environ. Manag. 91, 781-788. doi: 10.1016/j.jenvman.2009.10.009

Lu, H. L., Liu, B. B., Zhang, Y., Ye, J., and Yan, C. (2014). Comparing analysis of elements subcellular distribution in Kandelia obovata between SEM-EDX and chemical extraction. Aquat. Bot. 112, 10-15. doi: 10.1016/j.aquabot.2013.07.007

Lu, X. M., Sun, J., Guo, S. R., and He, L. Z. (2012). Effects of brassinolide on the mitochondria antioxidant system and cellular ultrastructure of cucumber seedling roots under hypoxic Stress. Acta Hort. Sin. 39, 888-896.

Lu, Y., Gong, Z. T., Zhang, G. L., and Burghardt, W. (2003). Concentrations and chemical speciations of $\mathrm{Cu}, \mathrm{Zn}, \mathrm{Pb}$ and $\mathrm{Cr}$ of urban soils in Nanjing, China. Geoderma 115, 101-111. doi: 10.1016/S0016-7061(03)00079-X

Malar, S., Vikram, S. S., Favas, J. C. P., and Perumal, V. (2014). Lead heavy metal toxicity induced changes on growth and antioxidative enzymes level in water hyacinths [Eichhornia crassipes (Mart.)]. Bot. Stud. 55, 54. doi: 10.1186/s40529014-0054-6
Malecka, A., Piechalak, A., Morkunas, I., and Tomaszewska, B. (2008). Accumulation of lead in root cells of Pisum sativum. Acta Physiol. Plant. 30, 629-637. doi: 10.1007/s11738-008-0159-1

Massaccesi, L., Meneghini, C., ComaCi, T., D’Amato, R., Onofrij, A., and Businelli, D. (2014). Ligands involved in $\mathrm{Pb}$ immobilization and transport in lettuce, radish, tomato and Italian ryegrass. J. Plant Nutr. Soil Sci. 177, 766-774. doi: 10.1002/jpln.201200581

McLaughlin, M. J., and Singh, B. R. (1999). “Cadmium in soil and plants: a global perspective," in Cadmium in Soils and Plants, ed M. J. McLaughlin and B. R. Singh (Dordrecht; Kluwer Academic Publishers), 13-21.

Qiu, Q., Wang, Y. T., Yang, Z. Y., and Yuan, J. G. (2011). Effects of phosphorus supplied in soil on subcellular distribution and chemical forms of cadmium in two Chinese flowering cabbage (Brassica parachinensis L.) cultivars differing in cadmium accumulation. Food Chem. Toxicol. 49, 2260-2267. doi: 10.1016/j.fct.2011.06.024

Ramos, I., Esteban, E., Lucena, J., and Gárate, A. (2002). Cadmium uptake and subcellular distribution in plants of Lactuca sp. Cd-Mn interaction. Plant Sci. 162, 761-767. doi: 10.1016/S0168-9452(02)00017-1

Sharma, P., and Dubey, R. S. (2005). Lead toxicity in plants. Braz. J. Plant physiol. 17, 35-52. doi: 10.1590/S1677-04202005000100004

Shen, H.,Wang, Y.,Wang, J., Xu, L., and Liu, L. (2015). Uptake, accumulation and transportation of lead among different genotypes in radish. Jiangsu J. Agric Sci.

Singh, B. (2001). "Heavy metals in soils: sources, chemical reactions and forms," in Proceedings of the 2nd Australia and New Zealand Conference on Environmental Geotechnics, eds D. W. Smith, S. G. Fityus, and M. A. Allman (Newcastle: Australian Geochemical Society), 77-93.

Su, Y., Liu, J. L., Lu, Z. W., Wang, X. M., Zhang, Z., and Shi, G. R. (2014). Effects of iron deficiency on subcellular distribution and chemical forms of cadmium in peanut roots in relation to its translocation. Environ. Exp. Bot. 97, 40-48. doi: 10.1016/j.envexpbot.2013.10.001

Tangahu, B. V., Sheikh Abdullah, S. R., Basri, H., Idris, M., Anuar, N., and Mukhlisin, M. (2011). A review on heavy metals (As, Pb, and $\mathrm{Hg}$ ) uptake by plants through phytoremediation. Int. J. Chem. Eng. 2011:939161 doi: 10.1155/2011/939161

Wang, X., Liu, Y. G., Zeng, G. M., Chai, L. Y., Song, X. C., Min, Z. Y., et al. (2008). Subcellular distribution and chemical forms of cadmium in Bechmeria nivea (L.) Gaud. Environ. Exp. Bot. 62, 389-395. doi: 10.1016/j.envexpbot.2007.10.014

Wang, Y., Xu, L., Chen, Y. L., Shen, H., Gong, Y. Q., Limera, C., et al. (2013). Transcriptome profiling of radish (Raphanus sativus L.) root and identification of genes involved in response to lead $(\mathrm{Pb})$ stress with next generation sequencing. Plos ONE 8:e66539. doi: 10.1371/journal.pone.0066539

Weigel, H. J., and Jäger, H. J. (1980). Subcellular distribution and chemical form of cadmium in bean plants. Plant Physiol. 65, 480-482 doi: 10.1104/pp.65. 3.480

Weng, B. S., Xie, X. Y., Weiss, D. J., Liu, J. C., Lu, H. L., and Yan, C. L. (2012). Kandelia obovata (S., L.) Yong tolerance mechanisms to Cadmium: Subcellular distribution, chemical forms and thiol pools. Mar. Pollut. Bull. 64, 2453-2460. doi: 10.1016/j.marpolbul.2012.07.047

Weng, G. H., Zhang, J. N., Zhang, D., and Zheng, J. T. (2009). Effect of exogenous lead on genotypic difference of lead content in grains of different rice varieties. J. Agro-Environ. Sci. 28, 2232-2235.

Wójcik, M., and Tukiendorf, A. (2014). Accumulation and tolerance of lead in two contrasting ecotypes of Dianthus carthusianorum. Phytochemistry 100, 60-65. doi: 10.1016/j.phytochem.2014.01.008

Wu, F. B., Dong, J., Qian, Q. Q., and Zhang, G. P. (2005). Subcellular distribution and chemical form of $\mathrm{Cd}$ and $\mathrm{Cd}-\mathrm{Zn}$ interaction in different barley genotypes. Chemosphere 60, 1437-1446. doi: 10.1016/j.chemosphere.2005.01.071

Xu, J., Yu, M. G., Chen, Y. X., Fu, X. P., and Duan, D. C. (2011). Characteristic of distribution and chemical forms of $\mathrm{Pb}$ in tea plant varieties. Chin. J. Appl. Environ. Biol. 22, 891-896.

Xu, J. L., Song, W. C., Bao, Z. P., Yang, J. R., and Liu, H. (1991). Chemical forms of $\mathrm{Pb}, \mathrm{Cd}$ and $\mathrm{Cu}$ in crops. Chin. J. Applied Ecol. 2, 244-248.

$\mathrm{Xu}$, P. X., and Wang, Z. L. (2013). Physiological mechanism of hypertolerance of cadmium in Kentucky bluegrass and tall fescue: Chemical forms and tissue distribution. Environ. Exp. Bot. 96, 35-42. doi: 10.1016/j.envexpbot.2013. 09.001 
Xu, Q. S., Min, H. L., Cai, S. J., Fu, Y. Y., Sha, S., Xie, K. B., et al. (2012). Subcellular distribution and toxicity of cadmium in Potamogeton crispus L. Chemosphere 89, 114-120. doi: 10.1016/j.chemosphere.2012.04.046

Zhang, Z. M., Jin, F., Wang, C., Luo, J., Lin, H. J., Xiang, K., et al. (2012). Difference between $\mathrm{Pb}$ and $\mathrm{Cd}$ accumulation in 19 elite maize inbred lines and application prospects. J. Biomed. Biotechnol. 2012:271485. doi: 10.1155/2012/ 271485

Zhao, F., McGrath, S., and Crosland, A. (1994). Comparison of three wet digestion methods for the determination of plant sulphur by inductively coupled plasma atomic emission spectroscopy (ICP-AES). Commun. Soil Sci. Plant 25, 407-418. doi: $10.1080 / 00103629409369047$

Zheng, M. Z., Cai, C., Hu, Y., Sun, G. X., Williams, P. N., Cui, H. J., et al. (2011). Spatial distribution of arsenic and temporal variation of its concentration in rice. New Phytol. 189, 200-209. doi: 10.1111/j.1469-8137.2010. 03456.x
Zhou, X. Y., Qiu, R. L., Hu, P. J., Li, Q. F., Zhang, T., Yu, F. M., et al. (2008). Effects of cadmium and lead on subcellular distribution and chemical form of zinc in Potentilla griffithii var. velutina. Environ. Sci. 29, 2028-2036.

Conflict of Interest Statement: The authors declare that the research was conducted in the absence of any commercial or financial relationships that could be construed as a potential conflict of interest.

Copyright $\odot 2015$ Wang, Shen, Xu, Zhu, Li, Zhang, Xie, Gong and Liu. This is an open-access article distributed under the terms of the Creative Commons Attribution License (CC BY). The use, distribution or reproduction in other forums is permitted, provided the original author(s) or licensor are credited and that the original publication in this journal is cited, in accordance with accepted academic practice. No use, distribution or reproduction is permitted which does not comply with these terms. 